\title{
AMERIKA SERIKAT MENCARI RUANG HIDUP DI SELURUH DUNIA
}

\author{
Oleh: \\ Gunardo RB \\ Jurusan Pendidikan Geografi FISE UNY
}

\begin{abstract}
Abstrak
Kajian terhadap suatu negara dalam perspektif Geografi Politik dapat menggunakan pendekatan fungsional. Pendekatan tersebut meliputi fungsi internal dan eksternal. Fungsi internal mencakup kekuatan sentripetal,kekuatan sentrifugal, ideologi negara dan organisasi intern. Sedangkan fungsi eksternal meliputi relasi teritorial, relasi elonomis, relasi politis dan relasi strategis. Amerika Serikat sebagai suatu negara adidaya dalam rangka mempertahankan ideologi kebebasan individunya rela berperang di seantero dunia, mulai dari tahun 1940-an di Eropa (Jerman) dan Asia (Jepang), tahun 1950an sampai kini di Asia (Korea , Vietnam, Afghanistan dan Irak). Perang-perang itu dilaksanakan dalam kerangka relasi politis (mempertahankan hegemoninya), relasi ekonomis (menjamin pasar bagi produk industri) dan relasi strategis (menjamin pasokan energi bahan bakar minyak). Dengan kata lain Amerika Serikat akan terus berusaha mendapatkan ruang hidup yang lebih luas bagi 191,1 juta penduduknya kalau tidak mau bubar seperti Uni Sovyet dan Yugoslavia.
\end{abstract}

Kata Kunci: Geografi politik, ruang 


\section{Pendahuluan}

Amerika Serikat (AS) adalah negara super power atau negara adi daya yang selalu mengisi berita-berita politik di seluruh dunia. Sejak Perang Dunia II tahun 1939 - 1945 peranan AS terus meningkat di seluruh dunia dan diseluruh bidang kehidup

an. AS memproklamirkan dirinya sebagai pembela demokrasi dan kebebasan individu, sehingga tak dapat tenang ketika ada negara lain yang mempunyai sistem politik yang berbeda. Cepat atau lambat AS akan bertindak untuk mempengaruhi negara tersebut dengan berbagai cara agar berubah menjadi negara demokrasi atau setidak-tidaknya menjadi negara yang tidak mengusik kepentingan AS. Pertanyaannya adalah benarkah AS bertindak hanya karena kepentingan politik dan bukan karena motif yang lain.

Salah satu kajian Geografi Politik adalah mempelajari negara sebagai keutuhan-keutuhan organis yang menempati ruang dan terlibat perjuangan konstan untuk mendapatkan Lebensraum (living area) yang lebih luas (Ratzel dalam Daldjoeni 1991). Dari kacamata Geografi Politik sepak terjang AS dapat dipahami sebagai upaya memperluas ruang hidupnya, mengingat jumlah penduduknya 299,1 juta (Population Reference Bureau, UNO,2006), hanya kalah dari China 1.331,4 juta jiwa dan India 1.121,8 juta jiwa.

Ruang hidup yang lebih luas dimaknai sebagai ruang bebas bagi AS untuk mendapatkan kebutuhan bagi penduduknya. Dan itu tidak harus menguasai secara politik deyure seperti zaman kolonialisme. Kajian Geografi Politik terhadap negara super power AS ini akan mengajak kita belajar bagaimana Indonesia ke depan dapat juga memenuhi kebutuhan hidupnya dengan menerapkan strategi politik yang tepat.. Sementara ini kita harus menerima kenyataan pahit kalau sebagian beras yang kita makan berasal dari Thailand dan Vietnam. Moda transportasi sebagian besar kita beli dari Jepang ( sepeda motor Honda, Yamaha dan Suzuki serta mobil Dayhatsu, Mitshubishi dan Toyota), Jerman (kapal penumpang sejenis Umsini dan Dobonsolo), AS dan Perancis (pesawat terbang Boeing dan Airbus). Alat-alat komunikasi hampir seluruhnya dari Norwegia (Nokia), Korea (Samsung) dan Jerman (Siemen). Susu, daging dan buah dari Australia.

\section{Amerika Serikat dan Perang Dunia II}

Selama Perang Dunia II berkobar AS menjadi risau ketika melihat Jerman menginvasi negara-negara tetangganya disebelah Barat yaitu Belgia, Belanda, Denmark, disebelah Selatan yaitu Perancis, Austria, 
Swiss, negara-negara Balkan , bahkan menyeberang sampai Afrika Utara, di sebelah Timur yaitu negara Polandia dan Uni Sovyet. AS merasa terusik kepentingannya dari dua sisi : politik dan ekonomi. Dari segi politik Jerman menjadi negara fasis diskriminatif, ketika menerapkan genocide terhadap warga keturunan Yahudi karena dianggap saingan bagi kaum Aria (asli penduduk Jerman) yang merasa menjadi mahluk paling unggul . Politik nasionalisme sempit yang diterapkan Partai Nazi, partai yang berkuasa di Jerman dibawah Kanselir Adolf Hitler menyebabkan jutaan orang tak bersalah mati sia-sia. Tragedi kemanusiaan ini yang menggerakkan pasukan AS menyeberang Samudera Atlantik dan mendarat di Normandia serta pantai-pantai Barat lainnya di Benua Eropa untuk membantu negara-negara di Eropa mengusir Jerman. Demi membela politik demokrasi AS yang kapitalis rela bekerja sama dengan pasukan Uni Sovyet yang komunis. Itulah dinamika kehidupan politik : tidak ada teman atau musuh abadi, yang abadi adalah kepentingan. Kepentingan AS adalah menjamin kebebasan berdemokrasi di seluruh Eropa, tetapi dari segi ekonomi menjamin terbukanya pasar bagi produkproduk AS dan terpenuhinya kebutuhan hidup bagi warganya dari produk Eropa. Sesungguhnya AS bersedia mengirimkan ribuan pasukannya ke Eropa karena dua alasan pokok yaitu politik dan ekonomi. AS berusaha agar Eropa yang bebas tetap menjadi living area (ruang hidup) nya.

Demikian pula ketika AS merasa terhina dengan keberanian Jepang membombardir Pearl Harbour di Hawai dengan pesawat-pesawat terbang Kamikaze (bunuh diri), AS melihat ancaman lebih besar kalau seluruh Asia dikuasai Jepang yang merupakan negara kekaisaran tetapi dikuasai militer (fasis).

Jumlah penduduk Asia merupakan $2 / 3$ nya jumlah penduduk dunia. Bagi AS jumlah penduduk sebesar itu adalah pasar yang luar biasa bagi produk-produk AS. Oleh karena itu AS tidak ragu-ragu meluluhlantakkan Hiroshima dan Nagasaki dengan bom nuklirnya

Jepang mengibarkan bendera putih dan berakhirlah Perang Dunia II.

Menurut Hartshorne apa yang diperbuat AS itu dalam kerangka memperkuat relasi politis dan relasi ekonomis. Pendekatan fungsional dari Geografi Politik memang mengkaji negara dari fungsi internal dan fungsi eksternal. Fungsi internal mencakup kekuatran sentrifugal, kekuatan sentripetal, ideologi negara dan organisasi intern. Sedangkan fungsi eksternal meliputi relasi teritorial, relasi ekonomis, relasi politis dan relasi strategis.

Kemenangan AS membebaskan Eropa dari invasi Jerman dan membebaskan Asia dari cengkeraman Jepang benar-benar menaikkan 
pamor AS sebagai negara super power atau negara adi daya yang tak terlawan. Bangsa AS menjadi bangsa yang merasa paling unggul dan dengan seenaknya mengatur kehidupan negara lain. Akan tetapi ternyata ada kekuatan lain yang mendasarkan diri pada kekuatan ideologi politik yaitu komunisme.

\section{Amerika Serikat dan Perang Dingin}

Perang Dunia II berakhir tahun 1945 dimana AS dan Uni Sovyet merasa menjadi pemenang. Wilayah-wilayah Eropa Barat tempat pasukan AS berperanan besar merasa AS menjadi payung yang mengayomi : Inggris, Belanda,Perancis, Belgia, Spanyol, Portugal dan Italia. Mereka bergabung dalam Pakta Pertahanan Altantik Utara (NATO). Sedangkan wilayah Eropa Timur yang berafiliasi dengan Uni Sovyet membentuk Pakta Warsawa : Polandia,Yugoslavia, Rumania, Cekoslovakia, Bulgaria, Hongaria dan Uni Sovyet. Negara Jerman terbelah menjadi dua negara yaitu : Jerman Barat dan Jerman Timur. Jerman Barat yang demokrasi masuk Pakta Pertahanan Atlantik Utara sedangkan Jerman Timur yang komunis masuk Pakta Warsawa. Kedua pakta yang saling berhadaphadapan seperti dua kubu atau dua blok yang siap tempur. Situasinya kadang panas kadang dingin. Apalagi setelah Uni Sovyet mampu membuat bom nuklir seperti yang dipunyai AS. Ancaman kehancuran dan kebinasaan seperti yang dialami Hiroshima dan Nagasaki rupanya membuat kedua blok yaitu Blok Barat dan Blok Timur merasa trauma dan takut untuk memulai sebuah perang. Muncullah perang ideologi : AS mempromosikan demokrasi dan Uni Sovyet melebarkan komunisme. Perang ideologi ini yang sering disebut Perang Dingin.

Pada tahap ini maka AS sedang memperkuat ideologi negaranya dengan menjalin relasi politis dan relasi strategis. Berbagai aliansi politik dikembangkan AS, salah satunya memindahkan markas Persatuan Bangsa-Bangsa dari Jenewa (Eropa) ke New York (AS).

Dengan demikian AS lebih mudah mengkontrol keputusan-keputusan politik yang diambil PBB. Seperti diketahui setiap keputusan politik PBB harus disetujui oleh anggota-anggotanya yang mempunyai hak veto. Mereka adalah AS,Perancis,Inggris, Uni Sovyet dan China. AS, Perancis dan Inggris mewakili Blok Barat. Uni Sovyet dan China mewakili Blok Timur. China yang waktu Perang Dunia II sangat dibantu Uni Sovyet secara perlahan menjadi kekuatan komunis yang mampu mengusir kekuatan nasionalis dari daratan China. Jadilah China yang komunis menguasai daratan China dan kaum nasionalis mendirikan Republik Taiwan. Segera AS menjalin hubungan diplomatik dengan Taiwan untuk memperkuat. 
aliansi politik strategisnya dalam rangka mengepung kekuatan komunis atau Blok Timur.

AS dalam masa Perang Dingin merupakan negara yang terus berperang, dengan dalih membantu negara sahabatnya. AS sangat khawatir bila suatu negara terpengaruh ideologi komunis ( baca Uni Sovyet dan China) maka kepentingan politik dan kepentingan ekonomi AS akan terganggu. Maka tahun 1950 - 1953 AS mengirimkan pasukannya ke Semenanjung Korea untuk membantu pasukan Korea Selatan yang demokratis melawan pasukan Korea Utara yang komunis. Hasilnya perdamaian Panmunjom yang membelah Korea menjadi dua negara Republik Korea yang demokratis di Selatan dengan ibu kota Seoul dan Republik Rakyat Demokratik Korea yang komunis di Utara dengan ibu kota Pyongyang. Sampai kini sebagian pasukan AS masih bertugas di Korea Selatan. Hal yang sama terjadi di negara Jepang dan Philipina dimana pasukan AS mempunyai hak mendirikan pangkalan militer untuk menjaga sahabatnya itu.

Kejadian yang agak lain dari hasil keterlibatan AS di Korea, Jepang dan Philipina adalah Perang Vietnam (1965-1975). AS sebagai negara super power betul-betul dipermalukan oleh kekuatan tentara Vietkong yang ibaratnya cuma mengandalkan perang gerilya dengan persenjataan tradisional. AS yang berusaha membantu Republik Vietnam Selatan

yang demokratis terpaksa harus merelakan 50.000 tentaranya menjadi jenazah melawan gempuran pasukan Vietnam Utara yang komunis dibantu gerilyawan Vietkong di wilayah Vietnam Selatan. Akhirnya secara dramatis AS melarikan diri setelah Saigon jatuh ke tangan Vietkong pada tanggal 30 April 1975. Negara Republik Vietnam Selatan bubar dan AS tidak meninggalkan satu orangpun pasukannya untuk mengepung komunismenya Uni Sovyet dan China.

Tetapi AS sukses menjadikan negara-negara Asia Tenggara ( Indonesia, Philipina, Malaysia, Singapura dan Thailand ) untuk tetap memilih sistem politik demokrasi dari pada sistem politik komunisme. AS tidak lagi melakukan strategi perang, melainkan menjalin relasi ekonomi yang erat dengan negara-negara Asia Tenggara. Jadilah Asia Tenggara menjadi pasar yang terbuka bagi produk-produk AS : Coca Cola, Dunkin Donat, Kentucky Fried Chicken, pesawat terbang Boeing, film-film Holywood. Perusahaan-perusahaan raksasa AS pun bebas mengekploitasi sumber daya alam : minyak bumi, gas alam, tambang dan hutan. Perusahaan perusahaan seperti Freeport, Exxon, Caltex, IBM, Hilton Inc adalah sebagian kecil yang mewakili kepentingan ekonomi AS secara keseluruhan. Bergeraknya perusahaan minyak bumi di Indonesia 
misalnya, akan menjamin kebutuhan bahan bakar minyak di AS. Dapat di mengerti bila AS sangat sensitif ketika sumber-sumber penghasil bahan bakar minyak di dunia tidak dapat dikuasai atau di luar kontrolnya. Kebutuhan bahan bakar minyak selalu meningkat bagi kelangsungan industri di AS. Pengalaman embargo minyak tahun 1974 oleh negaranegara kawasan Timur Tengah akibat Perang Israel-Palestina benar-benar memukul industri AS dan sekutunya seperti Jepang, Inggris dan Perancis.

Dalam masa Perang Dingin ini pula AS berusaha mengurangi pengaruh komunisme melalui tawaran-tawaran bantuan ekonomi bila suatu negara bersedia menanggalkan ideologi komunisme. Disamping itu AS melancarkan perang informasi langsung ke negara-negara komunis dengan mengajak rakyat setempat melihat dan merasakan bahwa kehidupan dibawah rezim komunis jauh lebih menderita dari pada kehidupan di negara-negara demokrasi. Tahun 1980 an adalah mulainya pengaruh komunisme rontok satu persatu, mulai dari Polandia yang melancarkan gerakan demokrasi, Cekoslowakia dilanda demonstrasi seniman-seniman yang menuntut demokrasi, Yugoslavia yang bergejolak dan puncaknya adalah runtuhnya Uni Sovyet sendiri oleh kampanye Pereztroika (Keterbukaan) dari sang Perdana Menterinya sendiri Michael Gorbachev. Yugoslavia resmi bubar tahun 2003, walaupun prosesnya sudah dimulai tahun 1900 ketika Herzegovina, Kroasia, Slovenia dan Masedonia memisahkan diri (Kompas, 6 Februari 2003) Perang Dinginpun usai tanpa harus ada korban karena bom nuklir. AS menjadi lega karena secara politis paham demokrasi telah mengalahkan paham komunisme. Akan tetapi urusan ruang hidup tak melulu urusan paham politik dan AS masih harus melanjutkan usahanya merebut ruang hidup bagi 199,1 juta rakyatnya , kalau perlu dengan perang. Kemenangan kapitalisme atas komunisme di Eropa, pengamat di negara Barat, khususnya AS, yakin kalau ingin berhasil maka negara-negara lain harus menempuh cara Amerika : membangun ekonomi pasar dan membangun demokrasi politik. (Juwono Sudarsono, Kompas 12-12-2000)

\section{Amerika Serikat dan Terorisme}

Tahun 1991 runtuhnya Uni Sovyet menandai selesainya Perang Dingin. Tapi bagi AS masih ada perang yang harus dijalankan. Kali ini sahabatnya di Timur Tengah yaitu negara Kuwait minta tolong karena tetangganya yang besar negara Irak mengklaim bahwa Kuwait adalah propinsinya dan menganeksasi tanggal 2 Agustus 1990 . Presiden Irak yang sangat berkuasa Sadam Husein merasa mampu menginvasi Kuwait, 
karena secara militer Irak jauh lebih kuat dan pengalamannya berperang selama 8 tahun dengan Iran merupakan bekal yang memadai.

Selama perang dengan Iran, sesungguhnya AS membantu dengan berbagai persenjataan. Namun ketika kepentingan ekonominya terusik, yaitu terhambatnya pasokan minyak dari Kuwait, maka AS dengan rela mengerahkan kekuatan militernya, baik darat ,laut dan udara untuk mengusir Irak dari bumi Kuwait. Operasi Badai Gurun digelar AS dan sekutunya tanggal 17 Januari 1991 (Kompas, 21 Maret 2003 halaman 10) Pesawat-pesawat terbang AS yang berpangkalan di Jerman,Italia dan Turki secara bergantian menghantam Kuwait yang diduduki Irak. Demikian pula kapal-kapal perang melancarkan peluru kendali jarak jauh Tomahawk dari Selat Hormuz. Akhirnya Irak menyerah dan AS pun dieluelukan rakyat Kuwait sebagai pahlawan. Pemerintah Kuwait menyediakan wilayahnya untuk pangkalan militer AS dan tentu saja menjamin kebutuhan minyaknya. Dengan demikian AS secara tidak langsung memperoleh basis di Timur Tengah Bagaimanapun juga secara strategis basis ini sangat penting mengingat di sebelah Timur negara Iran masih dianggap sumber terorisme dengan ide ekspor revolusinya. Ekspor revolusi yang bila diterapkan akan mengancam negara-negara yang bersifat kerajaan seperti Arab Saudi, Yordania dan Kuwait. Negara-negara kerajaan itu secara tradisonal menjadi sahabat AS, oleh karena itu AS merasa berkewajiban melindungi negara itu, walau tak dapat dipungkiri di balik itu ada kepentingan ekonomi. Ujung-ujungnya adalah ruang hidup yang diperebutkan.

Selesai Perang Kuwait, AS merasa agak tenang sedikit sampai Osama Bin Laden berhasil merontokkan Gedung Kembar World Trade Center dengan menabrakkan dua pesawat dan mengirim satu pesawat untuk merusak sebagian Pentagon. AS kembali terluka dan malu, persis seperti ketika Pearl Harbour dihajar Jepang dan pasukannya diusir Vietkong.

Negara super power, negara adi daya tak berdaya di negerinya sendiri, inilah pertama kali AS diserang di dalam negeri. Selama ini kalau perang pasti bukan di tanah Amerika, melainkan di Eropa, Asia atau Afrika. Osama Bin Laden telah membuat sejarah.

Bagaikan banteng terluka atau lebih tepatnya koboi ngamuk, AS segera mencanangkan perang terhadap terorisme. Presiden Bush jelas menunjuk Irak, Libya, Iran dan Korea Utara sebagai poros setan. Negara terakhir jelas karena ideologinya komunis. tetapi kalau Irak, Iran dan Libya adalah negara dengan mayoritas penduduk muslim. Dari sinilah konflik peradaban menurut Samuel Huntington diuji kebenarannya. 
Negara pertama yang menjadi sasaran amukan AS adalah Afghanistan. Alasan pertama penguasa Afghanistan waktu itu Mullah Umar dituduh menyembunyikan Osama Bin Laden. Kedua pemerintahan Afghanistan tidak demokratis karena menerapkan sistem otoriter, terlalu banyak aturan yang mengekang kehidupan warganya. Perang Afghanistan tidak terlalu lama karena AS tahu betul kekuatan pasukan Taliban. Pada waktu perang melawan Uni Sovyet, saat Afghanistan dikuasai kelompok komunis maka tentara Uni Sovyet berada di sana, pasukan Taliban mendapat bantuan AS melalui Pakistan. Jadi benar bahwa dalam politik tidak ada kawan abadi. Dulu Taliban dibantu karena menghadang komunis, sekarang Taliban dihajar karena dianggap teroris.

Rupanya setelah menguasai Afghanistan, AS belum merasa puas. Konon akibat kalah perang di Kuwait, Sadam Husein mengembangkan senjata pemusnah massal.Diduga Sadam Husein membuat bom-bom kimia, bom-bom syaraf dan bahkan mengembangkan senjata nuklir. Presiden AS menerima informasi yang kurang akurat, tetapi di telan begitu saja supaya ada alasan untuk menyalurkan semangat perang prajuritnya yang belum puas perang di Afghanistan. Lagi pula tragedi WTC benarbenar membuat

George W Bush kehilangan akal sehat. Walaupun tidak sepenuhnya disetujui PBB AS tetap melancarkan serangan ke Baghdad pada tanggal 20 Maret 2003. Alasan serangan militer yang berkali-kali diajukan Bush, Irak potensial menjalin hubungan dengan berbagai organisasi teroris dan memasok mereka senjata pemusnah massal . Tetapi publik membaca bahwa motivasi utama AS adalah penguasaan minyak. AS amat bernafsu menguasai sumber-sumber minyak Irak yang depositnya terbesar kedua di dunia setelah Arab Saudi ( Sudirman HN, 21 Maret 2003).

Seperti diketahui Sadam Husein sudah dipenggal, rakyat Irak sudah menyelenggarakan pemilu tahun 2005, tapi AS masih belum meninggalkan Irak. Irak menjadi negara yang tiap hari diguncang bom. Bagaimana akhir dari drama di Irak, tidak seorangpun tahu. AS rela mengorbankan 500 milyar dolar untuk biaya perang di Irak dan lebih dari 3000 tentaranya tewas demi menjaga politik demokrasi dan kepastian jaminan minyak bumi dari Irak sebagai sumber energi masa depan. 


\section{Penutup}

Sejak Perang Dunia II mulai tahun 1939 sampai kini tahun 2007 Amerika Serikat menja

di negara yang tidak pernah berhenti perang. Anehnya perang itu dilakukan jauh dari wilayah teritorinya, kecuali serangan ke Pearl Harbour oleh Jepang dan rontoknya gedung kembar World Trade Center oleh pengikut Osama bin Laden. Mulai dengan ramai-ramai mengeroyok Jerman tahun 1944 , menggempur Jepang tahun 1945, membantu Korea Selatan tahun 1950-an, mengebom Vietnam Utara tahun 1965-1975,

menggelar Operasi Badai Gurun di Kuwait tahun 1991, menggulung Afghanistan tahun 2002 dan terakhir menghukum Irak tahun 2003 sampai sekarang.

Amerika Serikat yang merasa menjadi negara terkuat setelah memenangi Perang Dingin

merasa perang yang dijalankannya dalam rangka menebarkan demokrasi politik dan membangun ekonomi pasar melawan pemerintah otoriter, diktator dan komunis. Tetapi patut diduga bahwa hal itu berkaitan pula dalam rangka mempertahankan hegemoninya menguasai ruang hidup bagi 1991,1 juta jiwa penduduknya dan menjamin pasar bagi produk-produk industrinya serta menjamin pasokan energi bahan bakar minyaknya. 
II Amerika Serikat Mencari Ruang Hidup di Seluruh Dunia

Daftar Pustaka

Daldjoeni.N. 1991. Dasar dasar Geografi Politik. Bandung : PT Citra Aditya Bakti

Miriam Budihardjo. 2002. Dasar dasar IImu Politik . Jakarta : PT Gramedia Pustaka Utama

Population Reference Bureau. 2006. Population Data Sheet. New York : PBB

Juwono Sudarsono. . Geopolitik dan Sistem Internasional. Kompas 12-122000

Sudirman HN. . Langkah Mundur Perangi Terorisme. Kompas 21-03-2003 Irak Abad Ke 20. Kompas. 21 Maret 2003. . halaman 10

Yugoslavia Tinggal Sejarah Kompas 6 Februari 2003. halaman 3 